\title{
PENGARUH TERAPI ZIKIR TERHADAP PENURUNAN TANDA DAN GEJALA HALUSINASI PADA PASIEN HALUSINASI
}

\author{
Emulyani $^{1)}$, Herlambang ${ }^{2)}$ \\ ${ }^{1,2}$ Program Studi S1 Keperawatan, STIKes Payung Negeri Pekanbaru \\ Email: emulyani38@yahoo.co.id
}

Diterima: November 2019, Diterbitkan: Juni 2020

\begin{abstract}
ABSTRAK
Halusinasi adalah salah satu gejala gangguan jiwa di mana pasien mengalami perubahan sensorik dalam persepsi indra, ketidakmampuan untuk membedakan rangsangan internal (pikiran) dan rangsangan eksternal (dunia luar), adanya persepsi yang salah tentang lingkungan tanpa benda. Dzikir atau dzikir secara etimologis didefinisikan sebagai kegiatan untuk mengingat Tuhan. Tujuan dari penelitian ini adalah untuk mengetahui pengaruh terapi zikir pada pengurangan tanda-tanda dan gejala halusinasi pada pasien halusinasi di RSJ Tampan Provinsi Riau. Jenis penelitian ini adalah kuantitatif dengan desain quasi-exprimental, dengan populasi semua pasien halusinasi di ruang Sebayang dan Indragiri dengan total 21 pasien. Sampel dalam penelitian ini adalah seluruh pasien yang menjalani halusinasi yang telah menjalani SP 1 (berteriak) dan SP 2 (berbicara dengan orang lain), dan alat untuk pengumpulan data menggunakan format penilaian perawatan jiwa dengan mengukur perhitungan frekuensi terjadinya halusinasi sebelum dan sesudah terapi diberikan zikir, menggunakan data analisis analisis bivariat dengan uji T. Diperoleh hasil bahwa nilai rata-rata keberhasilan kontrol halusinasi pada pasien halusinasi sebelum terapi dzikir adalah 16,90 dan setelah terapi zikir adalah 5,48 dengan nilai $\mathrm{p}=0,000<0,05$. Hal ini berarti ada pengaruh terapi zikir pada kontrol halusinasi pada pasien halusinasi. Perlunya terapi zikir dilakukan dalam pengelolaan layanan keperawatan dalam layanan standar prosedur operasional (SOP) pada terapi yang dijadwalkan.
\end{abstract}

Kata Kunci: $\quad$ Penurunan, Halusinasi, Terapi Zikir.

\begin{abstract}
Hallucinations are one of the symptoms of mental disorder in which the patient experiences sensory changes in perception of the senses, the inability to distinguish internal stimuli (thoughts) and external stimuli (outside world) perceptions about the environment without objects. Dhikr or dhikrullah is etymologically defined as an activity to remember God. The purpose of this study was to determine the effect of zikir therapy on the reduction of hallucinatory signs and symptoms in hallucinatory patients at RSJ Tampan Riau Province. This type of research is quantitative with quasi-exprimental design, with a population of all hallucinatory patients in Sebayang and Indragiri room with a total of 21 patients, in which the sample in this study was the entire population of patients undergoing hallucinations who had undergone SP 1 (screaming) and SP 2 (talking with others), and tools for data collection using the format of soul nursing assessment by measuring the calculation of the frequency of occurrence of hallucinations before and after therapy given zikir, using data analysis bivariate analysis with $T$ test, the results found that the value the average success of hallucinatory control in hallucinatory patients before the dhikr therapy was 16.90 and after zikir therapy was 5.48 with $p$ value $=0.000<0,05$ it was found that the effect of zikir therapy on hallucinatory control in hallucinatory patients. The need for zikir therapy is carried out in the management of nursing services in standard service of operational procedures (SOP) on scheduled therapy.
\end{abstract}

Keywords: $\quad$ Decline, Hallucinations, Zikir Therapy. 


\section{PENDAHULUAN}

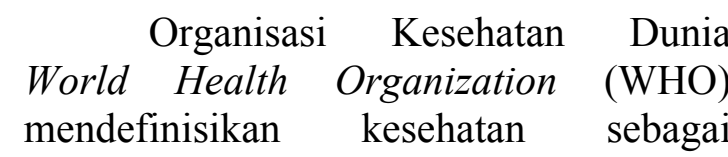
keadaan sehat fisik, mental, dan sosial, bukan semata-mata keadaan reproduksi tanpa penyakit atau kelemahan. Definisi ini menekankan kesehatan sebagai suatu keadaan sejahtera yang positif, bukan sekedar keadaan tanpa penyakit. Kesehatan jiwa merupakan bagian yang tidak dapat dipisahkan dari kesehatan dan merupakan unsur utama dalam terwujudnya kualitas hidup manusia yang utuh, salah satu ruang lingkup utama yang harus diperhatikan adalah kesehatan jiwa. (Videbeck, 2008) Kesehatan jiwa menurut Undang-Undang Republik Indonesia Nomor 18 (BAB I Ketentuan umum, Pasal 1, ayat 1) Tahun 2014, yaitu kesehatan jiwa adalah kondisi dimana seorang individu dapat berkembang secara fisik, mental, spritual, dan sosial sehingga individu tersebut menyadari kemampuan sendiri, dapat mengatasi tekanan, dapat bekerja secara produktif, dan mampu memberikan kontribusi. Apabila individu tersebut mempunyai masalah dalam kondisi kesehatan jiwanya maka resiko akan mengalami gangguan jiwa.

Gangguan jiwa adalah suatu sindrom atau pola psikologis atau perilaku yang paling penting secara klinis yang terjadi pada seseorang dan dikaitkan dengan adanya stress atau disabilitas atau disertai peningkatan resiko kematian yang menyakitkan, nyeri, disabilitas, atau sangat kehilangan kebebasan (American Psyciatric Association dalam (Videbeck, 2008)). Salah satu bentuk gangguan jiwa yang paling banyak saat ini adalah skizofrenia. Skizofrenia merupakan gangguan kesehatan jiwa yang dikategorikan dalam gangguan psikis yang paling serius karena dapat menyebabkan menurunnya fungsi manusia dalam melaksanakan aktivitas kehidupan sehari-hari seperti kesulitan dalam merawat diri sendiri, bekerja atau bersekolah, memenuhi kewajiban peran dan membangun hubungan yang dekat dengan seseorang.

WHO tahun 2015 menyatakan prevalensi gangguan jiwa adalah 465 juta jiwa di Dunia. Sedangkan berdasarkan National Institute of Mental Health, prevalensi gangguan jiwa diseluruh dunia sekitar $1,3 \%$ dari populasi diatas usia 8 tahun atau sekitar 53 juta orang di dunia menderita gangguan jiwa. Prevalensi gangguan jiwa di Negara berkembang dan Negara maju Relative sama, sekitar 21\% dari jumlah penduduk orang dewasa. Badan Pencatatan Sipil (BPS) 2015, prevalensi orang dengan gangguan jiwa di Indonesia mencapai 15,3\% dari 259,9 juta jiwa penduduk Indonesia. Berdasarkan data dari 33 Rumah Sakit Jiwa (RSJ) yang ada diseluruh Indonesia menyebutkan terdapat sekitar 2,5 juta orang menderita gangguan jiwa berat (Kesehatan, 2016).

Skizofrenia mulai muncul sekitar usia 15-35 tahun. Gejala-gejala yang serius dan pola perjalanan penyakit yang kronis berakibat disabilitas pada penderita skizofrenia. Gejala skizofrenia dapat di bagi menjadi dua yaitu gejala negatif dan gejala positif. Gejala negatif yaitu menarik diri, tidak ada atau kehilangan dorongan atau kehendak. Sedangkan gejala positif yaitu halusinasi, waham, pikiran yang tidak terorganisir, dan perilaku yang aneh. Dari gejala tersebut, halusinasi merupakan salah satu gejala utama psikosis skizofrenia. Halusinasi dapat melibatkan pancaindera dan sensasi tubuh (Videbeck, 2008)

Menurut (Yosep, 2016) pada pasien skizofrenia, $90 \%$ pasien mengalami halusinasi. Halusinasi adalah gangguan penerimaan pancaindra tanpa stimulasi eksternal (halusinasi pendengaran, penglihatan, pengecapan, penciuman, dan perabaan). Halusinasi merupakan salah satu gejala gangguan jiwa pada individu yang ditandai dengan perubahan sensori persepsi yaitu merasakan sensasi palsu berupa suara, 
penglihatan, pengecapan, perabaan atau penghiduan. Pasien merasakan stimulus yang sebenarnya tidak ada. (Keliat, 2011)

Stuart \& Laraia dalam (Yosep, 2016) menyatakan bahwa pasien dengan diagnosis medis skizofrenia sebanyak $20 \%$ mengalami halusinasi pendengaran dan penglihatan secara bersamaan, $70 \%$ mengalami halusinasi pendengaran, 20\% mengalami halusinasi penglihatan, dan $10 \%$ mengalami halusinasi lainnya

Berdasarkan laporan tahunan bidang keperawatan di Rumah Sakit Jiwa Tampan Provinsi Riaumulai dari tahun 2014 gejala halusinasi sebanyak 60,4\%, tahun 2015 gejala halusinasi sebanyak $73,56 \%$ dan sampai tahun 2016 gejala halusinasi sebanyak 72,82\%. Halusinasi menempati urutan pertama dari beberapa masalah keperawatan yang timbul pada tiga tahun. Intervensi dini yang komprehensif seperti pengobatan medis dan asuhan keperawatan sangat penting dilakukan agar dapat meningkatkan angka kesembuhan skizofrenia khususnya pasien dengan halusinasi (Maramis W F, 2004). Tindakan keperawatan menggunakan standar praktek keperawatan klinis kesehatan jiwa yaitu asuhan keperawatan jiwa (Stuart, 2016). Asuhan keperawatan jiwa bersifat spesifik, namun tetap dilakukan secara holistik. Dalam pelaksanaannya, tuntutan akan tindakan keperawatan secara independen dan progresif juga semakin dibutuhkan (Keliat, 2011)

$$
\text { Mengatasi halusinasi dapat }
$$

dilakukan dengan beberapa tahap, yaitu terapi fase akut dilakukan pada saat terjadi episode akut dari skizofrenia akut yang melibatkan gejala psikotik, terapi fase stabilisasi dilakukan setelah gejala psikotik akut telah dapat dikendalikan dan terapi tahap pemeliharaan dilakukan pada saat terapi pemulihan jangka panjang skizofrenia. Pada terapi pemulihan ini dapat dilakukan dengan terapi non farmakologi dan terapi farmakologi. Pada terapi non farmakologi ini dapat dilakukannya strategi pelaksanaan (SP) halusinasi dengan modifikasi terapi zikir. Dimana manfaat dari zikir ini adalah dapat menghilangkan rasa resah dan gelisah, memelihara diri dari was-was setan, ancaman manusia, dan membentengi diri dari perbuatan maksiat dan dosa, serta dapat memberikan sinaran kepada hati dan menghilangkan kekeruhan jiwa (Potter, 2012). Mekanisme bahwa terapi zikir bisa mengontrol halusinasi, yakni fungsi sistem saraf untuk mendeteksi, menganalisa, dan menghantarkan informasi. Informasi dikumpulkan oleh sistem sensorik, di intergrasikan ke otak adalah bagian otak depan (frotal lobe) dalam perencanaan, pengaturan, pemecahan masalah, perhatian, kepribadian, serta termasuk tingkah laku maupun emosi maka bagian otak depan disebut prefrontal cortex sebagai fungsi kognitif untuk menentukan kepribadian dan sinyal akan di teruskan ke otak bagian belakang terdiri dari premotor dan motor sebagai sistem motorik dan jalur otonom untuk mengontrol gerakan, aktivitas viserial, dan fungsi-fungsi endokrin. (Ikawati, 2014)

Berdasarkan jurnal (Hidayati, 2014) yang berjudul "Pengaruh Terapi Religius Zikir Terhadap Peningkatan Kemampuan Mengontrol Halusinasi Pendengaran Pada Pasien Halusinasi Di RSJD DR. Amino Gondohutomo Semarang" mendapatkan hasil analisa yang menunjukan ada pengaruh terapi religius zikir terhadap peningkatan kemampuan mengontrol halusinasi. Sejalan dengan penelitian oleh Sari, S.P, dan Wijayanti,D.Y dengan judul" Keperawatan Spiritualitas Pada Pasien Skizofrenia" mendapatkan hasil yaitu perlunya peningkatan spiritual yaitu dekat dengan Allah dan aktifitas ibadah yang bertambah rutin, sehingga bermanfaat dalam kesembuhan dari penyakit jiwa, manajemen symptoms, perubahan perilaku, perubahan emosi, dan perhatian pada masa depan. 
Berdasarkan survey awal peneliti menemukan respon pasien lebih nyaman dan tenang setelah melakukan zikir adalah $70 \%$ respon pasien pada bulan November 2017 di ruangan sebayang RSJ Tampan Propinsi Riau, namun kegiatan tersebut, tidak dapat dilaksanakan dengan baik dikarenakan fasilitas yang mendukung pasien untuk melakukan ibadah tidak ada, contoh; Ruangan khusus tempat ibadah pasien melakukan zikir setelah selesai sholat (Rumah Sakit Jiwa Tampan, 2016). Hal ini dapat di temukan pada saat melakukan intervensi keperawatan dan melakukan terapi aktivitas kelompok tentang pengontrolan halusinasi. Kegiatan tersebut diatas dilakukan pada pasien yang beragama islam. Hal ini berdasarkan studi pendahuan bahwa laporan akuntabilitas kinerja instansi pemerintah RSJ Tampan Provinsi Riau tahun 2016, dimana data distribusi pasien rawat inap yang beragama islam $98.8 \%$, dimana lebih banyak dari agama-agama lainnya yaitu budha $0.18 \%$, katolik $0.3 \%$,dan protestan $0.73 \%$. Sedangkan pasien dengan agama hindu dan konghucu tidak ditemukan (Rumah Sakit Jiwa Tampan, 2015) (Rumah Sakit Jiwa Tampan, 2014).

Dari data tersebut diatas, agama islam merupakan agama yang paling banyak yang mengalami gangguan jiwa yang dirawat di RSJ tampan Pekanbaru. Untuk memudahkan perawat jiwa dalam menjalankan perannya sebagai pemberi asuhan keperawatan, Rumah sakit perlu menyiapkan pemenuhan standard baik standar askep dan fasilitas yang memadai, standar askep telah di buat SOP tentang strategi pelaksanaan (SP) merupakan standar model pendekatan asuhan keperawatan untuk klien dengan gangguan jiwa dan pemasalahanya salah satunya pada pasien halusinasi. Sedangkan untuk fasilitas ruangan tempat ibadah pasien belum terealisasi sehingga pasien hanya menjalankan ibadah di ruangan masing-masing sehingga pelaksanaan ibadah tidak dapat dimaksimalkan.

Adapun tujuan dari penelitian ini adalah untuk mengetahui penurunan tanda dan gejala halusinasi pada pasien halusinasi sebelum dan sesudah pemberian terapi zikir serta untuk mengetahui pengaruh terapi zikir terhadap tanda dan gejala pasien halusinasi.

\section{METODE PENELITIAN}

Penelitian ini merupakan penelitian kuantitatif dengan design kuasi eksperimen tanpa control, dimana jumlah responden sebanyak 21 orang menggunakan purposive sampling, menggunakan analisis statistic uji $T$ dependent yaitu dengan membandingkan hasil sebelum dan sesudah dilakukannya terapi zikir terhadap gejala dan tanda halusinasi. Pelaksanaan terapi selama 7 hari di bimbing dan diarahkan serta diamati/observasi agar responden dapat melaksanakan sesuai tahapan yang di rencanakan.

\section{HASIL PENELITIAN}

Setelah dilakukan penelitian tentang pengaruh terapi zikir terhadap Tanda dan Gejala halusinasi pada pasien halusinasi di RSJ Tampan provinsi Riau. Analisis data karakteristik responden meliputi umur, jenis kelamin, dan umur akan di jelaskan pada tabel 1, sedangkan pengkajian halusinasi meliputi jenis halusinasi, situasi saat terjadi dan perasaan saat halusinasi di jelaskan pada tabel 2.

Tabel 1. Distribusi Karakteristik Responden Halusinasi RSJ Tampan Provinsi Riau

\begin{tabular}{rlll}
\hline No & \multicolumn{1}{c}{ Karakteristik } & $\begin{array}{c}\text { Jumlah } \\
(\mathbf{N})\end{array}$ & $\begin{array}{c}\text { Persentase } \\
(\%)\end{array}$ \\
\hline 1. & Umur & & \\
\hline a. $\quad \begin{array}{l}\text { Remaja Akhir (17 -25 } \\
\text { Tahun) }\end{array}$ & 1 & 42.9 \\
b. $\begin{array}{l}\text { Dewasa Awal (26-35 } \\
\text { Tahun) }\end{array}$ & 9 & 33.3 \\
c. $\begin{array}{l}\text { Dewasa Akhir (36-45 } \\
\text { Tahun) }\end{array}$ & 7 &
\end{tabular}




\begin{tabular}{|c|c|c|}
\hline $\begin{array}{ll}\text { d. } & \text { Lansia Awal (46-55 } \\
\text { Tahun) } \\
\text { e. Lansia Akhir (56-65 } \\
\text { Tahun) }\end{array}$ & $\begin{array}{l}3 \\
1\end{array}$ & $\begin{array}{c}14.3 \\
4.8\end{array}$ \\
\hline Total & 21 & 100 \\
\hline \multicolumn{3}{|l|}{$2 . \quad$ Jenis Kelamin } \\
\hline a. $\quad$ Laki-laki & 15 & 71,4 \\
\hline b. Perempuan & 6 & 28,6 \\
\hline Total & 21 & 100 \\
\hline \multicolumn{3}{|l|}{ 3. $\quad$ Pendidikan } \\
\hline a. $\mathrm{SD}$ & 12 & 57,1 \\
\hline b. SMP & 4 & 19,1 \\
\hline c. SMA & 5 & 23,8 \\
\hline Total & 21 & 100 \\
\hline \multicolumn{3}{|c|}{ Sumber : Analisis Data Primer 2018} \\
\hline \multicolumn{3}{|c|}{$\begin{array}{l}\text { Berdasarkan hasil analisa univariat } \\
\text { pada tabel } 1 \text { diketahui bahwa, umur yang } \\
\text { paling banyak adalah kelompok dewasa } \\
\text { awal (26-35 tahun) dengan jumlah } 9 \\
\text { responden (42,9\%), mayoritas jenis } \\
\text { kelamin laki-laki sebanyak } 15 \text { responden } \\
(71,4 \%) \text {, tingkat pendidikan yang } \\
\text { terbanyak adalah (SD-SMP) sebanyak } 16 \\
\text { responden }(76,2 \%) \text {. }\end{array}$} \\
\hline \multicolumn{3}{|c|}{$\begin{array}{l}\text { Tabel 2. Distribusi Pengkajian Responden } \\
\text { Halusinasi Di RSJ Tampan Provinsi Riau }\end{array}$} \\
\hline No $\quad$ Karakteristik & $\begin{array}{c}\text { Jumlah } \\
(\mathrm{N})\end{array}$ & $\begin{array}{c}\text { Persentase } \\
(\%)\end{array}$ \\
\hline \multicolumn{3}{|l|}{ 1. Jenis halusinasi } \\
\hline $\begin{array}{ll}\text { a. } & \text { Halusinasi } \\
& \text { Pendengaran }\end{array}$ & 10 & 47,6 \\
\hline $\begin{array}{l}\text { b. Halusinasi } \\
\text { Mulitple }\end{array}$ & 11 & 52,4 \\
\hline \multicolumn{3}{|c|}{ 2. Situasi saat terjadi halusinasi } \\
\hline \multirow{2}{*}{$\begin{array}{l}\text { a. Saat Sendirian } \\
\text { b. Saat Ramai }\end{array}$} & 21 & 100 \\
\hline & 0 & 0 \\
\hline \multicolumn{3}{|c|}{ 3. Perasaan saat halusinasi } \\
\hline a. Senang & 5 & 23,8 \\
\hline b. Tidak Senang & 15 & 71,4 \\
\hline $\begin{array}{l}\text { c. Senang dan Tidak } \\
\text { Senang }\end{array}$ & 1 & 4,8 \\
\hline
\end{tabular}

perasaan tidak senang sebanyak 15 responden $(71,4 \%)$,

Untuk mengetahui rerata tanda dan gejala halusinasi pre-post terapi zikir pada pasien halusinasi dapat di jelaskan pada tabel 3 .

Tabel 3. Gambaran Rerata Tanda dan

Gejala Halusinasi Pre-Post Terapi Zikir Pada Pasien Halusinasi di RSJ Tampan Provinsi Riau

\begin{tabular}{llll}
\multicolumn{3}{c}{ Provinsi Riau } \\
\multirow{2}{*}{$\begin{array}{c}\text { Karakteristik } \\
\text { Waktu }\end{array}$} & \multicolumn{2}{c}{ Mean } \\
\cline { 2 - 4 } & $\begin{array}{c}\text { Pre } \\
\text { Test }\end{array}$ & $\begin{array}{c}\text { Post } \\
\text { Test }\end{array}$ \\
& & \\
\hline & Pagi & 4.57 & 1.95 \\
2 & Siang & 1.14 & 0.19 \\
3 & Sore & 2.62 & 0.14 \\
4 & Malam & 8.57 & 3.19 \\
\hline \multicolumn{2}{l}{ Jumlah } & 16.9 & 5.48
\end{tabular}

Sumber : Analisis Data Primer 2018

Berdasarkan tabel 3 diatas dapat dilihat rata-rata terjadinya tanda dan gejala halusinasi sebelum dilakukan terapi zikir adalah 16.9 dan setelah di lakukan terapi zikir rerata tanda dan gejala halusinasi adalah 5.48. Untuk waktu yang menimbulkan gejala halusinasi yang paling banyak adalah pada malam hari dengan rata-rata kemunculan sebelum di lakukan terapi zikir 8.57 dan setelah terapi zikir berkurang dengan rata-rata 3.19 .

Analisa bivariat digunakan untuk melihat pengaruh terapi zikir terhadap Penurunan Tanda dan Gejala halusinasi pada pasien halusinasi di RSJ Tampan provinsi Riau. Hasil analisa bivariat yang diperoleh pada tabel 4.

Tabel 4. Pengaruh Terapi Zikir Terhadap Tanda dan Gejala Halusinasi Pada Pasien

\section{Halusinasi di RSJ Tampan Provinsi Riau}

Berdasarkan data pada table.2 didapatkan mayoritas jenis halusinasi multiple sebanyak 11 responden $(52,4 \%)$, keseluruhan situasi terjadinya halusinasi adalah saat pasien sendirian sebanyak 21 responden $(100 \%)$. mayoritas perasaan saat halusinasi pasien muncul ketika

\begin{tabular}{lccccccc}
\hline $\begin{array}{c}\text { Varia } \\
\text { bel }\end{array}$ & $\begin{array}{c}\text { Mea } \\
\mathbf{n}\end{array}$ & SD & SE & $\begin{array}{c}\text { Selisih } \\
\text { Nilai } \\
\text { Rata- } \\
\text { rata }\end{array}$ & $\begin{array}{c}\text { t- } \\
\text { hitung }\end{array}$ & $\begin{array}{c}\mathbf{P} \\
\text { Value }\end{array}$ & $\mathbf{N}$ \\
\hline $\begin{array}{l}\text { Pre } \\
\text { Test }\end{array}$ & 16,9 & 6,782 & 1,480 & 11,42 & 13,15 & & 21 \\
$\begin{array}{l}\text { Post } \\
\text { Test }\end{array}$ & 5,48 & 3,502 & 0,764 & 11,42 & 13,15 & 0,000 & 21 \\
\hline \multicolumn{7}{r}{ Sumber : Analisis Data Primer 2018 }
\end{tabular}

Sumber : Analisis Data Primer 2018 
Berdasarkan tabel 4 dapat dilihat nilai rata-rata frekuensi halusinasi pada pasien halusinasi sebelum dilakukan terapi zikir adalah 16,90 dan setelah dilakukan terapi zikir adalah 5,48 uji $T$ dependent di dapatkan $\mathrm{p}$ value $=0,000(\mathrm{p}<0,05)$, yang artinya ada pengaruh terapi zikir terhadap tanda dan gejala halusinasi pada pasien halusinasi.

\section{PEMBAHASAN}

Karakteristik responden dalam penelitian ini meliputi umur, jenis kelamin dan pendidikan.

Pada hasil penelitian ini didapatkan bahwa umur yang terbanyak pada kelompok usia dewasa awal (26 - 35 tahun) jumlah pasien 9 orang (42.9\%). Hasil penelitian ini menunjukkan bahwa onset pasien pada kelompok umur dewasa awal paling banyak. Sejalan dengan penelitian Damayanti, dkk tahun 2014 menyatakan bahwa umur yang menderita halusinasi mayoritas adalah dewasa awal sebanyak 73.5\%. Hal ini mungkin dapat disebabkan karena pada usia muda terdapat faktor lingkungan yang dapat mempengaruhi perkembangan emosional, dan adanya penyalahgunaan obat obatan. Kelompok usia ini merupakan usia produktif yang cenderung beresiko terjadinya halusinasi karena tahap kehidupan ini mempunyai stressor yang besar dan penuh tekanan. Pada kelompok usia ini gejala sudah dapat terlihat, walaupun beberapa tahun sebelumnya sudah muncul namun belum kelihatan (Yosep, 2016).

Sedangkan pada usia dewasa madya (41 tahun sampai 60 tahun) dan dewasa lanjut (61 tahun keatas) halusinasi ini dapat terjadi karena lebih banyak dipengaruhi oleh faktor biologik. Kirakira 90 persen pasien dalam pengobatan halusinasi adalah antara usia 15 dan 55 tahun (Potter, 2012)

Berdasarkan jenis kelamin diperoleh hasil pasien dengan jenis kelamin laki-laki sebanyak 15 orang $(71,4 \%)$ dan perempuan sebanyak 6 orang $(28,6 \%)$. Pada penelitian ini pasien laki-laki lebih banyak dari pasien perempuan. Penderita halusinasi paling banyak terjadi pada laki-laki. Gangguan kelainan jiwa pada laki-laki lebih dominan dibanding perempuan karena secara psikologis laki-laki mempunyai beban dan tanggung jawab yang lebih besar, sehingga stressor yang dihadapi juga lebih besar.Stress dapat ditimbulkan dari tekanan yang berhubungan dengan tanggung jawab yang besar yang harus ditanggungnya.

Untuk prognosis berdasarkan gender, lebih buruk laki-laki dari pada perempuan (Potter, 2012). Laki-laki cenderung sering mengalami perubahan peran dan penurunan interaksi sosial serta kehilangan pekerjaan, hal ini menjadi penyebab laki-laki lebih rentan terhadap masalah gangguan mental, termasuk depresi (Soejono, dkk 2000 dalam (Damayanti, 2014)).

Pada dasarnya laki-laki lebih cenderung sulit untuk mengontrol emosi, berbeda dengan perempuan, hal ini dapat disebabkan karena adanya efek neuroprotektif dari hormon perempuan dan kecenderungan yang lebih besar mendapatkan trauma kepala pada lakilaki karena mobilitas yang tinggi. Beberapa penelitian telah menyatakan bahwa laki-laki lebih mungkin mengalami halusinasi dari pada perempuan. Perempuan memiliki fungsi sosial yang lebih baik dari pasien lakilaki (Sadock, B. J., \& Sadock, 2010). Penelitian Damayanti dkk, th 2014, menyatakan bahwa laki-laki lebih banyak mengalami halusinasi $67,6 \%$ dibandingkan perempuan sebanyak $32,4 \%$.

Berdasarkan jenjang pendidikan didapatkan hasil penelitian responden mayoritas berpendidikan rendah (SDSMP) $76,1 \%$. Hal ini sejalan dengan penelitian Fahrul di RSJ Madani di Sulawesi Tengah tahun 2014 bahwa 
pasien mayoritas berpendidikan rendah sebanyak $54.1 \%$ dan tidak sekolah (13,5\%), Hasil penelitian ini menyimpulkan bahwa pasien dengan tingkat pendidikan rendah lebih mengalami kecendrungan untuk mengalami halusinasi. Tingkat pendidikan akan mempengaruhi cara berpikir dan status pekerjaan seseorang serta status social seseorang. Ketika seseorang tidak memiliki pendidikan atau pendidikan rendah maka akan berhubungan dengan pekerjaan dan penghasilan yang rendah.

(Potter, 2012) mengungkapkan kondisi klien yang tidak produktif dan tidak berpenghasilan menimbulkan stigma dimasyarakat bahkan juga di keluarga sehingga dapat mempengaruhi stigma diri dan membuat klien cenderung mengalami harga diri rendah. Pendidikan rendah, tidak bekerja dan tidak berpenghasilan memberikan kontribusi menurunnya harga diri dan mempengaruh kualitas hidup klien.

Dari hasil penelitian di dapatkan data jenis halusinasi responden mayoritas memiliki halusinasi multipel sebesar $52,4 \%$ (jenis halusinasi lebih dari satu) dan situasi saat terjadi halusinasi keseluruhan responden menjawab di saat sendirian sebanyak $100 \%$. serta mayoritas perasaan responden saat halusinasi datang di saat perasaan tidak senang sebesar $71,4 \%$, dan rata-rata waktu terjadinya gejala halusinasi paling banyak terjadi pada malam hari yaitu 8.57 (9) kali.

Dengan adanya data tersebut kita dapat mengidenfikasikan jenis halusinasi, situasi saat terjadinya halusinasi, perasaan pasien saat halusinasi, kapan waktu, frekuensi dan situasi munculnya gejala halusinasi yang dialami pasien sehingga dapat memberikan tindakan keperawatan yang sesuai dengan kebutuhan pada pasien halusinasi. Tujuan dari intervensi tersebut meliputi pertama pasien mengenali halusinasi yang dialaminya, yang kedua pasien dapat mengontrol halusinasinya, dan ketiga pasien mengikuti program pengobatan secara optimal (Keliat, 2011). Modifikasi tindakan keperawatan sangat dibutuhkan untuk membantu pasien mengurangi halusinasi sehingga pasien dapat mengoptimalkan kemampuannya dan pasien dapat hidup sehat dimasyarakat. Nilai spiritual dapat disandingkan karena spiritual mempengaruhi terjadinya sakit. (Stuart, 2016) menyatakan nilai spiritual dapat mempercepat penyembuhan.

Salah satu nilai spritualitas yang dapat di sandingkan agar gejala dan tanda halusinasi bisa menurun adalah dengan terapi zikir. cara terapi zikir yang dapat dilakukan adalah dengan lisan dan hati yang mensucikan nama Allah, memujiNya dan menyipari-Nya dengan segala kesempurnaan, kebesaran dan keindahan. Menurut surat al-ahzab (33:41-42) Allah SWT telah memerintahkan kepada orangorang yang beriman agar banyak berzikir. Dia berfirman " wahai orang-orang yang beriman! Ingatlah kepada Allah, dengan mengingat(nama-Nya) sebanyakbanyaknya dan bertasbihlah kepada-Nya pada waktu pagi dan petang. Surat albaqarah (2: 152) Dia berfirman " maka ingatlah kepada-Ku, Akupun akan ingat kepada mu". Surat ali imran (3:191) Dia berfiman" orang-orang yang mengingat Allah sambil berdiri, duduk atau dalam keadaan berbaring" sebagai aktivitas untuk mengingat Allah, adapun menurut istilah fiqih, dzikrullah sebagai amal qauliyah.

Sebelum melaksanakan aktivitas terapi zikir nilai rata-rata responden mengalami tanda dan gejala halusinasi sebanyak 16,9 (17) kali halusinasi yang muncul dan setelah dilakukan terapi zikir, nilai rata-rata responden mengalami tanda dan gejala halusinasi sebanyak 5,4 (5) kali. Terdapat penurunan nilai rata-rata munculnya tanda dan gejala halusinasi pada responden, hal ini disebabkan pasien telah mampu mengontrol tanda dan gejala halusinasi yang muncul dengan melakukan terapi zikir. Terapi zikir yang 
telah diajarkan peneliti diterapkan responden saat halusinasi muncul. Sehingga banyak diantara responden yang mampu menurunkan tanda dan gejala bahkan sampai menghilangkan halusinasi tersebut.

bahwa banyak pasien skizofrenia yang menggunakan agama dan atau spiritualnya sebagai alat koping. Hasil penelitian ini ditemukan berdoa, istigfar dan sholat dapat mengurangi gejala yang dialami pasien skizofrenia. Hal ini didukung oleh (Stuart, 2016) yang menyatakan spiritual koping dapat menjadi koping untuk symptom managemen pada pasien skizofrenia seperti halusinasi, hal ini sangat mampu untuk proses penyembuhan dan kekuatan bagi pasien.

Dilihat dari nilai rata-rata penurunan tanda dan gejala halusinasi pada pasien halusinasi sebelum dilakukan terapi zikir adalah 16,90 dan setelah dilakukan terapi zikir adalah 5,48 dengan hasil p value $=$ $0,000<0,05$. Artinya adanya pengaruh terapi zikir terhadap pengontrolan halusinasi pada pasien halusinasi.

Penelitian menunjukan bahwa sebelum dilakukannya terapi zikir pasien sering mengalami tanda dan gejala halusinasi. Setelah dilakukan terapi zikir, tanda dan gejala halusinasi berkurang bahkan pasien tidak mengalami gejala halusinasi lagi.

Penelitian ini dilaksanakan dengan mengumpulkan data dengan melihat hasil pengamatan pengontrolan halusinasi sebelum (pre test) dan setelah dilakukannya terapi zikir (post test).Pada penelitian ini telah dilaksanakan terapi zikir dengan teknik komunikasi terapetik terhadap pasien, yaitu komunikasi dalam rangka pemberian pelayanan kesehatan yang menyangkut interaksi antara pasien dengan perawat/petugas spritual.

Penelitian lain yang dilakukan (Hidayati, 2014) yang berjudul "Pengaruh Terapi Religius Zikir Terhadap Peningkatan Kemampuan Mengontrol Halusinasi Pendengaran Pada Pasien
Halusinasi Di RSJD DR. Amino Gondohutomo Semarang" Hasil analisis bivariat dengan uji wilcoxon menunjukkan ada pengaruh terapi religius zikir terhadap peningkatan kemampuan mengontrol halusinasi pendengaran diperoleh nilai $\mathrm{p}$-value $=0,000$, karena nilai $p<\alpha \quad(0,05)$ sehingga dapat disimpulkan terapi religius zikir berpengaruh terhadap peningkatan kemampuan mengontrol halusinasi pendengaran pada pasien halusinasi di RSJD Dr. Amino Gondohutomo Semarang.

Menurut peneliti, terapi zikir mempengaruhi terhadap pengontrolan halusinasi pasien. Pasien setelah melakukan terapi zikir mampu menguasai bahkan menghilangkan halusinasi disaat halusinasi tersebut datang. Sehingga pasien merasa tenang dan tidak merasa gelisah lagi.

Kelebihan dari penelitian ini adalah pasien dapat lebih mengenal cara berzikir yang baik dan bahkan pasien dapat lebih dekat dengan Allah SWT sebagai penciptanya. Kekurangan penelitian ini hanya pada jumlah pasien yang akan di uji, jika pasien banyak maka akan memakan waktu untuk melakukannya, serta perilaku pasien saat dilakukan terapi zikir, ada yang dapat mengerti dengan cepat dan ada juga yang butuh waktu untuk dapat mengerti cara melakukan terapi zikir tersebut.

\section{KESIMPULAN}

Di dapatkan hasil bahwa rata-rata tanda dan gejala halusinasi sebelum dilakukan terapi zikir adalah 16,90 (17) . Dan rata-rata tanda dan gejala halusinasi setelah dilakukan terapi zikir adalah 5,48 (5) kali. Serta ada pengaruh yang signifikan terhadap penurunan tanda dan gejala halusinasi yang di tunjukan dengan $p$ value $0,000(\mathrm{p}<0,05)$ 


\section{DAFTAR PUSTAKA}

Damayanti, J. dan U. (2014). Efektifitas Terapi Musik Klasik Terhadap Penurunan Tingkat Halusinasi pada Pasien Halusinasi Dengar di RSJ Tampan Provinsi Riau. Universitas Riau. https://doi.org/10.26699/jnk.v1i3.AR T.p230-235

Hidayati, W. . (2014). Pengaruh Terapi Religius Zikir Terhadap Peningkatan Kemampuan Mengontrol Halusinasi Pendengaran PadaPAsien Halusinasi Di RSJD Dr. Amino Gondohutomo Semarang. Jurnal Ilmu Keperawatan Dan Kebidanan.

Ikawati, Z. (2014). Farmakoterapi Penyakit Sistem Syaraf Pusat. Yogyakarta: Bursa Ilmu.

Keliat, B. A. dan A. (2011). Keperawatan Jiwa Terapi Aktivitas Kelompok. jakarta: EGC.

Kesehatan, K. (2016). Modul Bahan Ajar Cetak Kebidanan. Asuhan Kebidanan Neonatus, Bayi, Balita Dan Anak Pra Sekolah. Jakarta: Kemenkes RI.

Maramis W F. (2004). Ilmu Kedokteran Jiwa. Surabaya: Univesitas Air Langga.

Potter, P. \&. (2012). Buku Ajar Fundamental Keperawatan (4th ed.). Jakar: EGC.

Rumah Sakit Jiwa Tampan. (2014). Laporan Tahunan Bidang Keperawatan. Riau: RSJ Tampan.

Rumah Sakit Jiwa Tampan. (2015). Laporan Tahunan Bidang Keperawatan. Riau.

Rumah Sakit Jiwa Tampan. (2016). Laporan Tahunan Bidang Keperawatan.

Sadock, B. J., \& Sadock, V. A. (Eds. . (2010). Kaplan and Sadock's pocket handbook of clinical psychiatry. Lippincott: Williams \& Wilkins.

Stuart, G. (2016). Prinsip Dan Praktek Keperawatan Kesehatan Jiwa Stuart. Singapore. Singapore: Elsevier Inc.
Videbeck, L. S. (2008). Buku Ajar Keperawatan Jiwa. Jakarta: EGC.

Yosep, dan S. (2016). Buku Ajar Keperawatan Jiwa. Bandung: Refika Aditama. 